\title{
Artelogie
}

Recherche sur les arts, le patrimoine et la littérature de l'Amérique latine

$9 \mid 2016$

Horizons et perspectives de la culture en Colombie (1990-2015)

\section{Entrevista com Renato Janine Ribeiro}

\section{Gaspar Paz}

\section{(2) OpenEdition}

\section{Journals}

\section{Edição electrónica}

URL: http://journals.openedition.org/artelogie/945

DOI: 10.4000/artelogie.945

ISSN: 2115-6395

\section{Editora}

Association ESCAL

\section{Refêrencia eletrónica}

Gaspar Paz, «Entrevista com Renato Janine Ribeiro », Artelogie [Online], 9 | 2016, posto online no dia 20 junho 2016, consultado o 19 novembro 2020. URL : http://journals.openedition.org/artelogie/945 DOI : https://doi.org/10.4000/artelogie.945

Este documento foi criado de forma automática no dia 19 novembro 2020

Association ESCAL 


\title{
Entrevista com Renato Janine Ribeiro
}

\author{
Gaspar Paz
}

1 Renato Janine Ribeiro é doutor em filosofia e professor titular de ética e filosofia política da Universidade de São Paulo. Conhecido e respeitado por empregar novas práticas políticopedagógicas que valorizam o diálogo e a formação de consensos, reiterou esses valores quando atuou como Diretor de

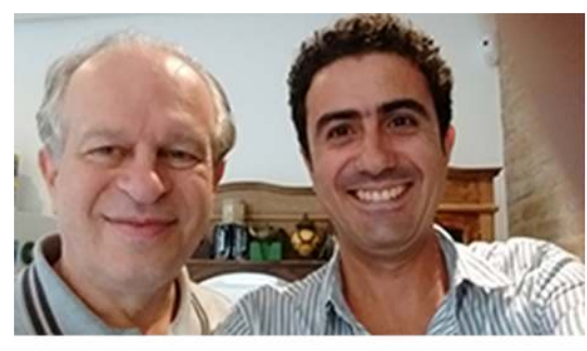
avaliação da CAPES e, mais recentemente, como Ministro da Educação. Publicou, entre outros livros, Ao Leitor sem Medo. Hobbes escrevendo contra o seu Tempo, Belo Horizonte, Ed. UFMG, 1999 e A Marca do Leviatã Linguagem e Poder em Hobbes, São Paulo, Ática, 2003. Nesta entrevista, Renato Janine Ribeiro fala sobre a transgressão nas artes e sua relação com a ética, com a estética, com a moral e a política. A partir de um panorama que perpassa as obras de Gustave Flaubert, Antonin Artaud, Marina Abramovic, Guimarães Rosa e o teatro brasileiro da década de 1960, o autor sublinha a importância da transgressão em seus momentos áureos (de 1850 até meados do século XX). Em seguida, discute a dificuldade e as limitações do ato transgressivo hoje, diante de um cenário no qual a inovação e a ruptura foram institucionalizadas. Nesse sentido, segundo o filósofo, a arte deixou de ser matéria de vida ou morte, como em algum momento o foi para Antonin Artaud ou para artistas que enfrentaram governos ditatoriais do século XX. Por fim, Renato Janine Ribeiro discorre sobre o atual momento da política brasileira e sobre os principais desafios nos campos da educação e da cultura.

2 Entrevista realizada por Gaspar Paz no dia 11 de março de 2016 na residência do filósofo Renato Janine Ribeiro, localizada no bairro Aclimação, em São Paulo. O áudio da entrevista foi editado por Daniel Tápia no estúdio de gravação do Centro de Artes da UFES. 
Entrevista com Renato Janine Ribeiro - Parte 1 (MP3 - 91.2 Mo): Os tempos áureos da transgressão e sua relação com a ética e a política

Entrevista com Renato Janine Ribeiro - Parte 2 (MP3 - 94.4 Mo): A transgressão na arte contemporânea

Entrevista com Renato Janine Ribeiro - Parte 3 (MP3 - 73.1 Mo): Os desafios da cultura e da educação no atual cenário político brasileiro 